This is the final peer-reviewed accepted manuscript of:

Battilani, P.; Bernini, C.; Mariotti, A. How to Cope with Dissonant Heritage: A Way towards Sustainable Tourism Development. Journal of Sustainable Tourism 2018, 26 (8), 1417-1436.

The final published version is available online at:

https://doi.org/10.1080/09669582.2018.1458856.

Rights / License:

The terms and conditions for the reuse of this version of the manuscript are specified in the publishing policy. For all terms of use and more information see the publisher's website.

This item was downloaded from IRIS Università di Bologna (https://cris.unibo.it/)

When citing, please refer to the published version. 


\title{
How to Cope with Dissonant Heritage: a Way towards Sustainable Tourism Development
}

\begin{abstract}
The UNESCO World Summit at Johannesburg in 2002, can be considered a watershed moment for promoting cultural diversity and defining cultural sustainability. Involving community residents is often regarded as best practice when fostering sustainability, though dissonant heritage problems may arise. Following the Tunbridge and Ashworth (1996) approach, we connect the issue of dissonance with contrasting interpretations of the past, specifically in the context of promoting heritage places linked to ideologies that are contrary to the principles enshrined in the Universal Declaration of Human Rights. We focus on buildings constructed during the interwar years in Predappio and Forlì, which are closely tied to Italian dictator Benito Mussolini, and now represent an "ambivalent and largely unwanted past" (Šešić and Mijatović 2014). Using a Lisrel model to analyse residents' attitude towards tourism around these dissonant heritage sites, we show that without a proper cultural policy (the ATRIUM route), residents view tourism unfavourably, rendering it unsustainable.
\end{abstract}

\section{KEYWORDS}

Dissonant heritage, history of fascism, sustainable tourism, ATRIUM route resident support, LISREL model

\section{Introduction}

Heritage is a fundamental part of a place culture and plays a key role in promoting cultural diversity. When local heritage is the basis for tourism, however, unwanted consequences may arise that threaten sustainability. For example, issues related to the area's carrying capacity or conflicting opinions on how cultural resources should be employed can undermine permanent residents' support for tourism. Focusing on dissonant heritage places (Tunbridge \& Ashworth, 1996; Ratz, 2006), our research aims to investigate whether such areas can become sustainable tourist destinations and if proper cultural policies are required.

Cultural heritage always carries the messages and the values of today's society as the result of a selection process. The current generation identifies and "interprets" what elements, of that infinite set provided by history, deserve preservation and "sacralisation" (Tunbridge \& 
Ashworth, 1996). Consequently, contrasting interpretations of the past may arise and create a situation of competing meanings (Ashworth \& Tunbridge 1996). The dissonance emerges when there is more than one community or group creating their own discourse about the same cultural heritage places. Some scholars extend this concept and consider dissonance as a constituent attribute of heritage (Smith, 2006). In this paper, however, we maintain the distinction between dissonant and non-dissonant places. Following Šešić and Mijatović (2014), we focus on "an ambivalent and largely unwanted past", specifically in the context of a totalitarian ideology. These regimes rejected democratic principles and did not uphold the rights enshrined in Universal Declaration of Human Rights. Furthermore, they had their own 'authorised heritage discourse', to borrow from Smith (2006).

Around the world, many situations have created dissonance such as the colonial past (Tunbridge \& Ashworth, 1996) or the slave trade to provide labour for sugar and tobacco plantations (Dann \& Seaton, 2001; Roushanzamir \& Kreshel, 2001). In Europe, the most striking examples can be found in the interwar fascist and the post-war communist heritage (Goulding \& Domic, 2009; Wight, 2016). To investigate issues of tourism sustainability in communities marked by dissonant heritage we focus on the two neighbouring Italian towns of Forlì and Predappio. The urban landscapes of these two areas still bear witness to the public works financed by the Italian fascist regime, during the interwar years and are, consequently, a constant reminder of the symbolic meaning they held in the fascist ideology.

Dissonant heritage places comprise different risks from issues related to removing contentious historical contexts (Roushanzamir \& Kreshel, 2001; Goulding \& Domic, 2009) to political manipulation by extremists supporting racial and ethnic exclusiveness or totalitarianism (Tunbridge \& Ashworth, 1996). For this reason, in the aftermath of a profound and dramatic historical change, the symbols of past ideologies or values are often hidden or actively marginalized as the result of "unintentional disregard" or "societal amnesia" (Hollinshead, 1992).

In line with the literature on place identity and tourism sustainability, we analyse whether dissonant heritage pushes permanent residents into holding a negative attitude towards tourism and if best practices can be developed to mitigate or avoid this risk. To this aim, a survey was carried out in Forlì and Predappio in 2013, to gather information on how permanent residents rank place image, dissonant heritage (as an indicator of place identity), their knowledge of 
architectural style and attitude towards tourism. A structural equation model (LISREL) was estimated from this data.

The result of our investigation shows that dissonant heritage influences permanent resident support for tourism. Residents can be favourable towards heritage tourism, which is based on their unwanted past, although when the heritage discourse takes the shape of a nostalgic tour of fascism, support fades away. In conclusion, dissonant heritage places can be sustainable tourist destinations, provided an appropriate heritage management is implemented.

To better interpret these findings, two features should be highlighted: involving residents as active agents in the collective debate on dissonant heritage; and overcoming the parochial or national narrative by creating an international perspective. In this respect, the 2014 creation of the European Cultural Route, named ATRIUM (Architecture of Totalitarian Regimes of the $20^{\text {th }}$ Century in Europe's Urban Memory) was a crucial step.

\section{Can Dissonant Heritage Contribute to the Residents' Attitude Towards Tourists? Participation of the Local Community in Tourist Development}

Over the last decade, local community attitude toward tourism has been extensively analysed by sociologists and economists (Andereck \& Nyaupane, 2011; Gursoy, Chi \& Dyer, 2010; Lee, Kang, Long \& Reisinger, 2010). Tourist planning studies have defined a plurality of participatory schemes aiming at involving residents in tourist destination development (Iorio \& Corsale, 2014; Hall, 2008; Kontogeorgopoulos, Churyen \& Duangsaeng, 2014). Several factors can explain this focus on residents, from the changing scope of planning activities to the emergence of a new definition of sustainability. As planning activities move from the choice of the most suitable location for facilities and infrastructure to the definition of projects pursuing social responsibility, cultural promotion as well as economic development, the traditional top down approach has been abandoned in favour of bottom up models. Therefore, involving locals has become essential (Timothy, 2011). At the same time, the concept of sustainability has been evolving from a purely environmental dimension to the inclusion of social and cultural aspects embracing the quality of life in the local community.

The extensive literature on resident involvement in tourist activities can be divided into four main categories: studies focusing on the driving factors shaping permanent residents' support (take for instance the countless papers using both social exchange theory and social identity 
theory); studies assessing the impact of the residents' involvement in terms of long term sustainability (Carmin, Darnall \& Mil Homens, 2003; Scheyvens, 1999); studies dealing with the connection between the residents' involvement and tourist sector profitability (Schroeder, 1996; Carmin, Darnall, Mil \& Homens, 2003); and, finally, studies analysing the impact of the residents' perceptions (in terms of place attachment, place identity or place image) on their support for tourism development (Gursoy \& Rutherford, 2004; Stylidis, Biran, Sit \& Szivas 2014).

Our investigation falls into this last strand of literature, with an investigation into whether place identity based on dissonant heritage (Identity), together with the knowledge of this heritage (Knowledge) and the place image (Place Image) influence permanent resident support for tourism (Support). These links are described in Figure 1 where the endogenous latent variable Support is explained by three explicative latent variables Place Image, Knowledge, Identity.

$<$ Insert Figure 1>

\section{The Connection between Heritage and Place identity}

The starting point of this study is the connection between heritage and place identity. Heritage plays a key role in characterizing places and can stimulate, strengthen, or weaken the community's identity. It can be described as an anchor for the identity of any place. For example, the use of heritage for Nation building has been widely documented (Graham \& Howard, 2008; Smith, 2006; Harvey, 2008). Heritage also strongly affects the place identity at the local or regional level. Given that it is a socially constructed idea (Crang, 2004), place is dynamic (McCabe \& Stokoe, 2004), and changes over time. Negotiations among users (individuals and social group), but also between different generations can shape and re-shape places. Discourse on the meaning and value of heritage plays a crucial role in this dynamic process, which not only strengthens or weakens place identity but even defines the key features of identity itself.

Using the identity process theory (Breakwell, 1986; Twigger, Ross \& Uzzell, 1996), Hawke states that place can contribute to identity through several factors: continuity across time, selfesteem, distinctiveness, and self-efficacy. At least three of these factors are strongly affected by some sort of heritage (Hawke, 2010). Self-esteem can be associated with the sense of pride people feel when they live near a heritage site such as living in a historic town (Twigger-Ross \& Uzzell, 1996, p. 209). Continuity across time comes from the fact that heritage is perceived 
as an anchor for identity when the social and economic context is changing. In fact, place can be considered "a topology of memories: a sedimented, folded, undulating terrain of associations and memories - and as one continually reconfigured by new eruptions of memory..." (Atkinson, 2007, p. 523). Distinctiveness follows from the conviction of the originality or uniqueness of heritage. Davis, Huang \& Liu (2008) found that communities tended to enhance their cultural heritage to strengthen local identities and help community sustainability.

Apart from being an anchor for identity, heritage can be related to residents' perception in many other ways. Heritage can contribute to the place image together with other aspects of community life. The significance of place image shaping people's attitude comes from psychology (e.g., Lynch, 1960) and geography (e.g., Bolton, 1992) where place image is the sum of beliefs, ideas and impressions people hold of a place (Crompton, 1979). It can be conceptualized as the perception of "specific attributes" of a place from scenery or nightlife (Echtner \& Ritchie, 2003; Gallarza, Saura \& García, 2002) to "universal attributes" such as public services, safety, green (Stylidis, Biran, Sit \& Szivas, 2014; Ramkissoon \& Nunkoo, 2011; Schroeder,1996; Chen \& Tsai, 2007; Echtner \& Ritchie, 2003). Among the attributes of place, it is important to note that the perceived quality of local heritage plays a vital role. In this case, heritage is not considered a part of the local identity but as a component of the image that residents have of the town where they live.

\section{When Heritage is Dissonant}

In the literature, the interaction between place identity and heritage has not been extended to include the effect of dissonance, which, however, can weaken the driving factors of place identity. The first element to disappear is self-esteem when dissonance prevents people from feeling proud of the place they live in. The unwanted past becomes an unwanted place. The second is continuity across time. The emergence of dissonance is often the result of a newly erupted memory, changing the landscape so profoundly that it no longer functions as an anchor for identity. Finally, if dissonant heritage is used to highlight the uniqueness of a place, the distinctiveness can assume a negative connotation.

At this point, we need to clarify the concept of dissonant heritage in the context of our case studies, where we turn to Tunbridge and Ashworth (1996) who state that even if a certain degree of dissonance is implicit in the nature of heritage itself, there are monuments, practices or memories, which deserve specific attention due to the origin and features of their dissonance. 
In their view dissonance can be considered an attribute of place, which is dependent on its past plus the existence of conflicting communities or heritage users. They listed different sources of dissonance: a) dissonance implicit in commodification; b) dissonance implicit in place products and c) dissonance implicit in the content of message. Our research is contextualized in their third origin of dissonance that emerges directly from history itself, when abrupt political and cultural changes reverse the meaning of existing symbols and values. In these cases, the past becomes an unwanted past.

To understand the nature of this type of dissonance we can also borrow the concept of authorized heritage discourse from Smith (2006). Following the theoretical framework of Critical Discourse Analysis, Smith introduces the issue of the power relations at the base of heritage discourse. In any society, the dominant groups use their own view of the past when identifying important monuments as well as the experts responsible for preserving them. This is the authorized heritage discourse, which is exclusive and expression of a hegemonic power. The excluded communities can only create their own discourse, in contrast to the dominant one. Therefore, heritage is dissonant by definition because it comes from a social process that aims both at legitimizing and at working out, contesting and challenging a range of cultural and social identities (Smith 2006, p. 82).

Some scholars only recognize one authorized heritage discourse in history (Smith 2006), which originated in the nineteenth century, promoted nationalism and liberal modernity, invented the concept of Western universalism (Smith, 2006) and stimulated a wave of preservation laws. However, the concern with heritage or material items of the past is part of the human condition (Harvey, 2001) and an accurate historical analysis allows other authorized discourses to emerge. Tracing the history of heritage preservation provides evidence of the role the past and art have played in shaping place identity. In Europe, the first laws were introduced by the Papal State between 1425 and $1574^{1}$. Very soon afterward, experts were hired, such as the painter Raphael who became an Inspector of Fine Art. At this moment in time, the concept of heritage only included works of art (usually religious subjects), ruins from past civilizations and books

\footnotetext{
1 The 1425 Papal Bull Etsi de cuctarum issued by Martino V preserved the Ancient building of Rome; the 1462 Papal Bull Cum almam nostram urbaem issued by Pio II prohibited the demolition of ruins; the 1474 Papal Bull Cum provida Sanctorum Patrum issued by Sisto IV prohibited the alienation of the work of arts kept in churches; the 1574 Papal bull Quae publice utilia issued by Gregorio XIII introduced limitation to the private appropriation of cultural heritage.
} 
(Battilani, 2007a and 2017). The authorized heritage discourse was based on the concept of urban decorum and on the idea of church universalism (Raffaello Sanzio, 1515).

The nineteenth century heritage discourse was not the first and will not be the last. Since the 1960s, some of its basic factors have been challenged. For example, the idea that only grand, old, tangible and aesthetically pleasing monuments deserve to be preserved. In this respect, the Venice Charter for the Conservation and Restoration of Monuments and Sites adopted on the occasion of the Second International Congress of Architects and Specialists of Historic Buildings in 1964 was an important watershed; article 1 broadened the subject of conservation to various social and economic aspects of the past (Petzet 2004). Despite the innovative stance of Article 1, the role this charter played by in overcoming the nineteenth century authorized discourse, remains uncertain and has been questioned by some scholars (Smith 2006). The second pivotal moment came in 2003 with the adoption of the Convention for the Safeguarding of the Intangible Cultural Heritage at the 32nd session of the UNESCO General Conference. It was the end of a long process that started in the 1980s, if not even the 1950s (Blake, 2001). Since then, such a variety of new "monuments, goods or practice" have been included in local, national and international heritage, to push Lowenthal, a critical cultural historian, into exclaiming: "All at once heritage is everywhere - in the news, in the movies, in the marketplace - in everything from galaxies to genes" (Lowenthal, 1996). This progressive extension of the subjects to be conserved, paved the way for a change in the authorized heritage discourse, which is ongoing and can be seen in the pluralizing of communities and stakeholders involved.

In this framework, it is important to stress that during the interwar period, the fascist regime promoted a distinctive view of the past, which culminated into its own dominant heritage discourse. After the Second World War, there was a profound change and the new élites supporting democratic values began shaping a new dominant heritage discourse. As a consequence, the heritage of the interwar years can be narrated through two conflicting authorized heritage discourses, the old (dating back to the fascist period) and the new. The main difficulty in providing new meaning to the fascist heritage is therefore, the presence of a hegemonic discourse coming from the past and promoting values conflicting with democratic principles and universal human rights.

Clearly, a strong dissonance can produce undesirable effects both on the sense of place and on tourism sustainability, not to mention political and social risks. In this context, it is crucial to 
promote a critical memory of the fascist heritage. Quoting Smith: "for effective change to be initiated an explicit and critical recognition of the cultural and political nature and consequences of the authorized heritage discourse does need to be made" (p.88).

\section{Forlì and Predappio from Fascism to Democracy}

To understand the dissonance included in the Italian heritage, it would be useful to summarize what happened during the interwar years. After World War I, the growing dissatisfaction with the economic and political situation, along with a certain degree of social unrest, pushed the progressive transformation of the young Italian democracy (universal suffrage for men was introduced in 1914) into a dictatorial regime (De Felice, 2005). The decisive moment came in 1922 when the king appointed Benito Mussolini as Prime Minister, leading to an end of the democratic experience after only a few short years. Mussolini, the dictator, remained in power until 1943 when a military government took over, which led the way to an alliance with the USA and the United Kingdom and a return to democracy after the war. During his administration, Mussolini started new colonial campaigns, signed an alliance with Hitler, enacted laws against Jews, intimidated and persecuted (often to death) political opponents and brought his own country into the catastrophe of the Second World War, siding with Germany. He adopted sophisticated political strategies to create propaganda and secure the social consensus. Some welfare policies for the middle class and the poor were adopted, mass media was subject to censorship and the cult of personality was introduced in Italy. Many of these policies included the construction of new buildings and entire districts or villages, according to the prevailing architectural styles of the time, in other words, based on Rationalism. Therefore, because Italian Rationalism followed Fascism, their histories are intertwined and difficult to separate. Rationalist architecture, "born in the wake of the Fascist revolution, could be seen... at once as a true child of Fascist revolution and as a faithful heir of the Roman Empire as Fascism proclaimed itself to be" (Ghirardo, 1980, p. 119). What remains of those buildings and urban designs aimed at celebrating the Fascist revolution and values, is now the Italian dissonant heritage.

In Predappio and Forlì the use of architecture to celebrate and glorify the dictatorship was particularly strong since it was the birthplace of Mussolini himself. He was born in 1883, in Predappio, a small village about 15 kilometres from Forlì, and lived there until 1902, when he 
moved to Switzerland. Moving back to Italy in 1906, he lived for a few years in Forlì. The attention to his home towns began quite early, as part of the cult of personality In the second half of the 1920s, the paths between the places in his life became a sort of political pilgrimage for teachers, students, Fascist supporters and average citizens. The starting point was the Forlì railway station and the great boulevard in front of it, then the journey continued to Predappio to visit the house where he was born, the school where his mother taught and the cemetery. This kind of tourism was so important to the city of Predappio that it became necessary to open a true tourist office offering photo services, souvenirs and a place to have a lunch at the Casa del Fascio (House of the Fascist Party) (Giovannetti, 2010). Summer camps along the river were also organized for children, in addition to a new cycling race that was introduced, the Predappio-Rome Race. The symbolic value of this route is easy to understand (La Stampa, 14 September 1930).

The urban design of both towns was heavily modified. The city of Forlì improved its standing in the Italian urban hierarchy, moving up to a central position in political and economic aspects of life. Impressive public works were realized to render Forlì the embodiment of the Fascist ideology, and a synthesis of the modern spirit and rural nostalgia. During the interwar years a "fascist district", along 800 meters of the main boulevard leading to the railway station, was built. It was the essence of Fascist ideology and a visible summary of its political agenda: the modern spirit (a Railway station and an Aeronautical college), a welfare state designed to build consensus for the dictatorship (houses for civil servants), political dominance over society by controlling recreational activities and the school system (the Fascist youth organization Balilla House and the Industrial Technical Institute), and the nationalist rhetoric of sacrifice (the Memorial to Fascists who died for their Country). A second group of buildings reshaped the city centre and the main square: a large Post office, the Courthouse, and State office buildings. The inauguration of these buildings was often mentioned in the national press, which contributed to Forli becoming part of the Italian collective consciousness (La Stampa, 29 December 1938; La Stampa, 21 August 1932; La Stampa, 7 October 1941; La Stampa, 19 September 1936; La Stampa, 1 August 1935).

Predappio underwent even greater changes where an entirely new town was built. This New Predappio was created with buildings symbolising social and political power, which were ideally connected both to Mussolini's birthplace and to the monumental cemetery (where his mother is buried); a sort of triumphant way to pay homage the dictator and his family. In 
conclusion, during the interwar years the local identity of the two towns was completely rewritten around the symbols and values of Fascism.

At the end of the Second World War, both Forlì and Predappio started their new lives as democratic municipalities. From a political point of view, they had always been run by left oriented local governments. The economy in Predappio continued to be based on agriculture while Forlì became rapidly industrialized thanks to the emergence of a multitude of new small and middle sized enterprises (Fauri, 2012). At the end of the 1970s, the two towns had broken any political or economic ties to the dissonant past.

However, the buildings, with all their symbolic meaning, continued to stand as visible reminders of an urban landscape created during a moment that many wanted to forget. What's more, a revival of political pilgrimage itineraries could easily take hold, especially in Predappio, where it became increasingly difficult to deny that people might arrive to relive the nostalgia of fascism. In 1957, the Italian government granted the Mussolini family permission to bring the dictator's body to Predappio and bury him in the family's tomb. A week after the burial, a crowd of 3,500 people arrived, marking the beginning of a new nostalgic tour to visit the dictator's tomb and homestead (La Stampa, 31 August 1957; La Stampa, 3-4 October 1957; La Stampa; 10 August 1972; La Stampa 30 July 1983). Since then, against the will of the town, Predappio is host to those Italians who are still nostalgic for fascism, usually three times per year (on the anniversary of his birth, death, and the March on Rome).

It was easier for Forlì, to obscure its ties to the dictator in the absence of any strong signs referring to his private life. We can say that Forlì has dissonant places and Predappio has both dissonant and nostalgic places.

In their 1996 book, Tunbridge and Ashworth suggested three possible best practices to manage dissonant heritage: 1) close dialogue between all the communities or groups of people competing in the use of heritage 2) minimalism 3) inclusivism. The first point is suitable for situations where the same resource is the reference point for more than one community and therefore multiple and sometimes contrasted heritage interpretations can be offered. This is often the situation of border regions. This solution was clearly not suitable for Predappio and Forlì, nor for Italy in general. The political dimension of that heritage made it impossible to create a dialogue between people nostalgic for fascism and that part of population who had fought for democracy. 
The obvious choice for Italy was minimalism and Predappio and Forlì were no exception. A narrative supporting democracy and peace was developed. Where possible, the old symbols were re-worded and included in the new public discourse (or authorized discourse) otherwise they were cast aside. For example, after the war, the 1932 Forlì memorial for Fascist martyrs became a monument in honour of all victims of all wars. For many decades in Forlì, the rationalist/fascist heritage simply disappeared.

Predappio tried a "minimalist" approach, at least at the beginning. Many of the rationalist buildings became part of the normal political, social and economic life and were used as schools, public offices and such. However, the minimalism route was difficult to pursue here, and after 1957, Mussolini's tomb started attracting hundreds of nostalgists. Predappio's residents moved from minimalism to a sort of passive cohabitation with a nostalgic interpretation of their dissonant past. The Fascist authorized heritage discourse continued to be re-told even after the new authorized narrative, promoting democratic values emerged.

In conclusion, minimalism was the preferred strategy for at least four decades. Of course, this did not overcome the dissonance but allowed the problem to be postponed to an era when the memories of fascist atrocities were not so fresh.

\section{How to Deal with Dissonant Heritage: from Minimalism to Inclusivism}

The policies in Forlì, over the last twenty years, can be described as the passage from minimalism to inclusivism through a process including residents and visitors. Fifteen years ago, Forlì began a new and important urban planning phase, addressing the cultural dimensions of the city's surroundings. The most tangible and evident result was the opening of the Musei di San Domenico (a museum compound of 5 buildings) in December 2005, which became the cultural hub of the town, and host to the majority of local cultural events, workshops and exhibitions. The Musei di San Domenico have played a pivotal role in re-shaping the cultural image of the town, by integrating Forlì into the regional network of cities of art.

The second milestone in the cultural "rebirth" of Forlì is in the facelift on dissonant heritage. In order to avoid revisiting the past by creating an aestheticized or filtered version, the rediscovery of the city's Rationalist heritage (the starting point of an inclusivism strategy) was managed by creating a European cultural route on the architecture of totalitarian regimes (i.e., the ATRIUM project). 
In 1999, a national level exhibition "The planned city" was organized at the Musei di San Domenico, focusing on the Rationalist heritage in Forlì and the surrounding area. For the first time, the city started a collective debate in a local public space (but with national visibility), around the architectural narratives of fascism. Mediated by the technical nature of architecture, this initial approach to dissonant heritage was considered acceptable by the local population, because discussing the aesthetical, stylistic, and functional values created a natural limit in referencing the dissonant values of the buildings.

Given the left-wing political orientation of the local government in Forlì, over the previous decades, the political situation could ensure that no attempts of revisionism would be carried out. The debate on $20^{\text {th }}$ century Forli can continue; photography contests, local history books, and cultural events encouraged increasing numbers of citizens to interest themselves in the dissonant architecture.

A new twist in the process from minimalism to inclusivism came in 2009 and 2010: the municipality won a 2 million euro project within the South-East Europe territorial cooperation programme.

This 3 years project, ATRIUM - Architecture of Totalitarian Regimes in Urban Management, was led by the City of Forlì and counted 18 partners from 11 different South-Eastern European countries. All the partners had experienced a totalitarian regime during the $20^{\text {th }}$ Century and were currently managing a dissonant architectural heritage (Figure 2). Even though the dictatorial regimes date back to different decades, the buildings realized under these totalitarianisms share some key features: large structures, a strong impact on the urban landscape, and inclusion of all the living experiences within the government ideological framework. As it is based on the main buildings and urban landscapes of past authoritarian European regimes, ATRIUM was able to collect the values this dissonant heritage embodies, which Europe currently and unequivocally renounces. The project aimed at encouraging a shared view of European identity that is able to face the uncomfortable and contradictory aspects of the Twentieth Century history.

\section{<Insert Figure 2>}

The ATRIUM project has played a decisive role in influencing the choices of cultural and urban development in Forlì and its surroundings. Namely, in 2014 the CoE awarded ATRIUM (www.atriumroute.eu) as one of the Cultural Routes of the Council of Europe, a programme of transnational cooperation running since 1987 (Berti, Penelope \& Mariotti, 2014). 
The CoE acknowledgement, based on a set of evaluation criteria of the activities carried out by the route, implies a shift from architecture to culture and history thanks to an inclusive approach based on participation.

These initiatives target local residents and visitors, but in a transnational perspective, since the aim of a $\mathrm{CoE}$ Cultural Route is to mobilise and bring together a large number of individuals, organisations, institutions and structures in Europe, and thereby contribute to the process of European identity construction. This set of activities (over 30 per year) organized by the route, has shifted the attention from architecture to the relationship between dissonant heritage, urban spaces and people's lives.

Interviews carried out with local administrators, have shown that decisions and interventions in the urban spaces over the history of the city in the $20^{\text {th }}$ Century are the results of a selfgenerating process fuelled by the growing number of local associations involved in ATRIUM's cultural activities. The type and number of events, contribute to an enriched debate and body of knowledge around urban development, cultural assets and cultural tourism growth on the dissonant heritage places.

It could be said that the shift from a minimalist to an inclusive approach has been supported by a supranational tool of cultural promotion (the transnational cultural route), based on strong involvement by residents and city users who, thanks to their participation in the events, are active agents in the collective debate on how to deal with their dissonant heritage.

The role of the administration is to support this process of inclusion, while keeping the dissonant value of this heritage alive. This is the reason the cities along the Cultural Route play a key role in the international context.

\section{Research Methods}

To investigate the residents' attitude towards tourism in the presence of dissonant heritage, we administered a survey to permanent residents in Forlì and Predappio in 2013. The survey allows us to analyse the relationship between identity, knowledge of Rationalism, place image and residents' attitude towards tourism, by means of a Lisrel model.

\section{Sampling and Data Collection}

The target population consisted of permanent residents of Forlì and Predappio. Out of a population of 116,196 and 6,480 residents, a total of 216 and 319 residents were interviewed, 
respectively for Forlì and Predappio. The sample was stratified based on the population structure (i.e., age and gender). Data were collected from March to April 2013 (i.e., during the week-ends) using a structured questionnaire that was administrated by professional interviewers. Residents were randomly approached in the main areas of the two towns (i.e., main streets, squares and market squares). The survey was conducted respecting ethics guidelines adopted in social research (Oldendick, 2012). ${ }^{2}$

The response rate was high; about $90 \%$ of the residents approached agreed to participate in the survey. Some descriptive statistics about samples are reported in Table 1.

$<$ Insert Table 1>

\section{Questionnaire}

The questionnaire comprised four main sections. The first section aimed to measure residents' place image by asking participants to what extent they agree with certain attributes of Forlì and Predappio, using a Likert-type scale (1 - strongly disagree, to 5 - strongly agree). The item attributes were derived from previous literature on both residents' destination and destination image (Among others: Stylidis et al., 2014; Ramkissoon \& Nunkoo, 2011; Schroeder,1996; Chen \& Tsai, 2007; Echtner \& Ritchie, 2003; Gallarza et al., 2002). In particular, the selection of attributes would reflect the residents' experience of the place, as a place to live and work, a clean place with green areas as well as a safe place to live. Particular attention was also given to the quality of the artistic, cultural and historical heritage of the destination.

The second section focused on the link between heritage (dissonant monuments included) and place identity. It is important to highlight the difference between the two towns. Due to its long history, Forlì has both Dissonant (the rationalist/fascist architecture) and Ancient heritage (the Musei di San Domenico, the Basilica of San Pellegrino, the Abbey of San Mercuriale, Albertini Palace, The Cathedral, etc.); on the contrary, Predappio is a newly founded city dating back to the fascist years and therefore its entire heritage is dissonant. However, two monuments have a higher degree of dissonance, because they are linked to Mussolini's private life (his tomb and

\footnotetext{
2 The survey is based on a voluntary participation and informed consent. These principles guarantee that all respondents are choosing to participate in the survey of their own free will and that they have been fully informed regarding the research project. The potential respondent was fully informed prior to completing the survey and was competent to decide to participate, free from any coercion. Ethics standards used in the survey also protect the confidentiality and anonymity of the subjects. Researchers did not share information between participants and have procedures in place to protect the data and names of participants.
} 
the cemetery); we named them Nostalgic dissonant heritage while the other buildings are defined as Dissonant heritage. This distinction describes the degree of difficulty in creating a new heritage discourse.

We asked residents to indicate which monuments best represented the place identity by means of a Likert-type scale (1 - strongly disagree, to 5 - strongly agree).

A further set of questions regarded the residents' knowledge of Rationalism in order to measure awareness of their town's dissonant heritage. Residents were asked if they knew both the architectonic style and the political origin of their town's heritage.

Finally, residents' support for tourism development was measured with three statements: residents' support for tourism development in general (Ko \& Stewart, 2002; McGehee \& Andereck, 2004); residents' willingness to be involved in experiences increasing the knowledge of Rationalist architecture; residents' support for the ATRIUM cultural route.

\section{Data Description}

From the analysis of the questionnaires, many similarities and a few differences between Forlì and Predappio emerge (Figure 3). The place image is positive in both towns, though the level of agreement is higher in Forlì than in Predappio.

\section{$<$ Insert Figure 3>}

Residents have a very good knowledge of their dissonant heritage (Figure 4): in both towns about $90 \%$ believe there are buildings important to the history of architecture; $89 \%$ in Forlì and $100 \%$ in Predappio are able to date the origin back to fascism; 57\% in Predappio and 68\% in Forlì know the architectural style.

\section{$<$ Insert Figure 4>}

Regarding the contribution of different monuments to the place identity, in Forlì the Rationalist buildings rank third after two Ancient heritage monuments; in Predappio the nostalgic dissonant heritage ranks first. In conclusion, for many residents all the problems associated with the dissonance, belong to the place identity, even though the ancient heritage is more deeply-rooted (Figure 5).

\section{<Insert Figure 5>}


The survey questions aimed at measuring the residents' support for tourism have provided these results (Figure 6): residents are in favour of an increase in tourist arrivals (Forlì 94\%, Predappio 91\%) and are interested in developing tourist itineraries based on Rationalist architecture (Forlì $86 \%$, Predappio 96\%). The differences between the two towns deserves some attention because it is crucial in terms of tourism sustainability. Having experienced non-sustainable nostalgic tourism makes the Predappio residents less supportive of tourism development and more interested in developing Rationalist itineraries that would be able to transform the nostalgic tourism into cultural tourism. As for the willingness to participate in cultural experiences to increase knowledge on Rationalism, the agreement is a little bit lower (77\% Forlì and 73\% Predappio). This result seems connected both to the level of education and to job: the more interested people have a secondary school diploma or a bachelor's degree and are teachers, office workers, managers, students or housewives (all data are available on request from the Authors). The Bourdieu acculturation theory can help us explain the residents' preferences.

$<$ Insert Figure 6>

\section{Construct Measurement and Validation}

We have identified four main latent constructs for which, measurement items are presented in Table 2. The first is the Image that residents have of their town, a concept that has no connection with the idea of dissonance. To measure this variable, we used the resident evaluations about the environment as a proxy (i.e. standard of living; green areas and cleanliness), social and cultural activities (i.e. places for leisure and socialization; cultural and recreational activities), and the cultural and heritage offering. The second is the Knowledge of heritage in terms of historical period, architectural style, that capture the residents' degree of awareness about dissonant heritage. The third is the town Identity connected with the different types of cultural heritage: ancient heritage, dissonant heritage and nostalgic dissonant heritage.

<Insert Table 2>

In assessing a model's reliability, the loading of each indicator on its associated latent construct must be calculated and compared to a threshold. Generally, the loading should be higher than 0.7 for indicator reliability to be considered acceptable (Hair, Black, Babin \& Anderson, 2010). Table 3 shows that the majority of the indicator loadings on their corresponding latent factors 
are higher than 0.7; only a few indicators loaded between 0.4 and 0.7 , indicating that they might otherwise be considered for removal based on the AVE (the AVE reflects the amount of variance captured by the construct in relation to the amount of variance due to measurement error). To establish convergent validity, the AVE of the factor should be higher than 0.5 (Chin, 2010; Hair et al., 2010) and in this study, all the AVE values were above 0.5 (Fornell \& Larcker, 1981; Hair et al., 2010), or very close to it as with the case of Environment for Forlì (0.49) and Support in Predappio (0.48). Therefore, we concluded that it was unnecessary to remove any of the indicators used in the models with loadings ranging 0.4-0.7.

\section{$<$ Insert Table 3>}

\section{Structural Model Estimates}

The structural relationships between residents' place image, identity, knowledge of Rationalism and residents' support for tourism development were tested by means of a structural equation model (LISREL). The results indicate a good fit for both the structural models (with ChiSquare $=58.37$ and 575.60, p_value $>0.00 ; G F I=0.99$ and 0.92; RMSEA=0.02 and 0.14 for Forlì and Predappio, respectively), confirming that the hypothesized models are a significant representation of the empirical data. The hypothesized relationships (paths) constituting the structural model are in general significant but with different direction and intensity in the two destinations (Table 4).

This model allows us to assess how place image (in terms of socio-cultural activities, environment, and quality of cultural heritage) place identity (expressed by the ancient, dissonant and nostalgic heritage) and knowledge on dissonant heritage impact on resident's support for tourism.

Place image has a contrasting impact: the appreciation for the socio-cultural activity is statistically not significant in both towns; appreciation for the environment has a negative impact on Predappio and is not significant for Forlì; and finally, appreciation for cultural events has a positive impact for Forlì and is not significant for Predappio. The results can be explained in terms of local cultural and environmental policies. Predappio is situated in a beautiful landscape of hills and its residents are, above all, worried about the environmental effects of tourism development. Forlì is experiencing a "cultural rebirth" and the majority of residents appreciate their local heritage and are more supportive of tourism development. 
The cultural awareness (the knowledge residents have on the local dissonant heritage) has a contrasting impact on the residents' attitude towards tourism: it is positive for Predappio and negative for Forlì. Evidently, in Predappio a deeper knowledge of dissonant heritage results in the desire and also the ability to imagine a new kind of tourism, based on a new narrative (for instance Rationalist architecture) more than on nostalgic feelings supporting the Fascist authorized discourse. So, the more they know, the more supportive they are of tourism. Forlì has a variety of cultural heritage sites to offer tourists. In this case, the more residents know about dissonant heritage the more worried they are about using it to attract tourists.

On the contrary, the place identity variables positively affect both towns with the only exception of the nostalgic dissonant heritage. In this regard, three aspects deserve attention. First, the fact that dissonant heritage is perceived as a component of the local cultural heritage. Second, when this feeling is stronger, the willingness to support tourism is stronger. We could comment on this result saying that the identity dimension overcomes the knowledge dimension. Concerns related to dissonant heritage become weaker when a feeling of belonging emerges. The last comment concerns the negative impact of the Predappio nostalgic dissonant heritage. People identifying the Mussolini tomb and the Cemetery as the main local heritage, prefer to reject tourism development in order to head off the arrival of fascism nostalgia in this small village.

\section{$<$ Insert Table 4>}

We can read the findings in terms of the issue we raised in the introduction. Dissonance negatively influences the residents' support for tourism when the Fascist authorized heritage discourse overcomes the current narrative as happens with the nostalgic places. The ATRIUM route as well as the city's cultural activities have contributed to strengthening a new authorized discourse in an international perspective, which improves the sustainability of heritage use and the resident's attitude toward tourism.

\section{Conclusions}

This paper aims at investigating whether dissonant heritage may be transformed into a driver of sustainable tourism at a destination. We focus on Forlì and Predappio and analyse the permanent residents' attitude towards tourism, considering the role of identity, image of the place and knowledge of totalitarism. There are two significant findings. First, dissonant heritage 
marginalization cannot carry on forever even in a "non-tourist" or forgotten town. As a matter of fact, when cultural rebirth became the focus of local government policies in Forlì, it was also necessary to provide a narrative for the buildings identified as dissonant places. The survey results show that appreciation for cultural events has a positive impact for Forlì and is not significant for Predappio. Since the 1990s, Forlì has passed from minimalism to inclusivism. The cultural mediation and all the cultural activities organized by the City of Forlì and the private cultural associations, have constructed a critical memory and provided the community with the skills necessary to deal with this dissonant heritage. Even though the process has not been completed, it has allowed Forlì to welcome a growing number of visitors while avoiding any sort of nostalgic pilgrimage. Cultural awareness has a contrasting impact on the residents' attitude towards tourism: it is positive for Predappio and negative for Forlì. Evidently in Predappio a deeper knowledge of dissonant heritage results in the desire for and the ability to imagine a new kind of tourism, based on a new narrative (for instance Rationalist architecture) more than on nostalgic feelings supporting the authorized discourse of fascism. So, the more residents know, the more supportive they are of tourism. From this point of view, the strategy implemented by the municipality, using a transnational cooperation tool - the ATRIUM route to foster inclusivism, has been crucial in replacing the dissonant value of the local heritage on an international scale, and helps local authorities with a difficult rebranding strategy.

The second main result of our investigation is that a community can create a strong tie with its cultural heritage even when dissonance is perceived and the memory is contested. At present, both Forlì and Predappio's residents consider the Rationalist buildings to be part of their cultural identity and they are interested in sharing their memories with tourists. The only exception is the nostalgic dissonant heritage of Predappio. Specifically, the Predappio residents who identify the cultural heritage of their place with Mussolini's tomb don't support tourism development. This is a consequence of the unwanted nostalgic tourism that has marked Predappio since the 1950s and the failure of "minimalism". In other words, we can say that in nostalgic places, dissonance negatively influences permanent resident support for tourism when the "unwanted" authorized heritage discourse overcomes the current narrative.

To conclude, sustainable tourism development based on dissonant assets is possible only by building a critical memory in the local area and involving the local population. In addition, transnational cooperation strategies can contribute to achieving this result. The experiences in Predappio and especially, Forlì can be defined as a best practice, and the results provided in 
this paper and the methodology adopted, may also prove useful to the discussion on the role of dissonant heritage in other countries, when it comes to developing tourism around it.

\section{References}

Andereck, K.L., \& Nyaupane, G.P. (2011). Exploring the nature of tourism and quality of life perceptions among residents. Journal of Travel Research, 50(3), 248-260.

Atkinson, D. (2007). Kitsch geographies and the everyday spaces of social memory. Environment and Planning, 39 (3), 521-540.

Battilani, P. (2007a). The Relationship between Cultural Tourism and Heritage Management in Italy during the Past two Hundred Years, in M. Dritsas (ed.) European tourism and culture. History and National perspectives, Athens: Livanis Publishing Organization, 225 -249 .

Battilani, P. (2017). Si fa presto a dire patrimonio culturale. Problemi e prospettive di un secolo di patrimonializzazione della cultura. Storia e futuro, 45 (12), 1-12. http://storiaefuturo.eu/si-presto-dire-patrimonio-culturale-problemi-prospettive-unsecolo-patrimonializzazione-della-cultura/.

Berti E., Penelope D., \& Mariotti A. (Eds) (2015). Cultural Routes management from Theory to Pratice. Step by Step guide to the Council of Europe Cultural Routes, Strasbourg, Council of Europe Publishing (also in French).

Blake, J. (2001), Developing a New Standard-setting Instrument for the Safeguarding of Intangible Cultural Heritage Elements for consideration, UNESCO documents, CLT2001/WS/8 Rev.

Bolton, R. (1992). Place Prosperity vs People Prosperity’ Revisited: An Old Issue with a New Angle. Urban Studies, 29(2), 185-203.

Breakwell, G.M. (1986). Coping with Threatened Identities, London and New York: Methuen.

Carmin, J., Darnall, N., \& Mil Homens, J. (2003). Stakeholder Involvement in the Design of U.S. Voluntary Environmental Programs: Does Sponsorship Matter?, Policy Studies Journal, 31(4), 527-543.

Chen, C., \& Tsai, D. (2007). How destination image and evaluative factors affect behavioral intentions? Tourism Management, 28(4), 1115-1122. 
Chin, W. (2010). How to write up and report PLS analyses. In V. Vinzi, W. Chin, J. Henseler, \& H. Wang (Eds.), Handbook of partial least squares: Concepts, methods and applications (655-690). Heidelberg, Germany: Springer.

Crang, M. (2004). Cultural geographies of tourism, in M. Hall, A. Williams, A. Lew (Eds.), A companion to tourism: Companions to geography, Blackwell, Oxford.

Crompton, J.L. (1979). Motivations for Pleasure Vacations. Annals of Tourism Research, 6 (4), 408-424.

Dann, G.M.S., \& Seaton, A.V. (Eds) (2001). Slavery, Contested Heritage and Thanatourism. New York.

Davis, P., Huang, H., \& Liu, W. (2008). Heritage, local communities and the safeguarding of "spirit of place" in Taiwan. Museum and Society, 8(2), 80-89.

De Felice, R. (2005). Mussolini il rivoluzionario. ET saggi, Einaudi Editore: Torino.

Echtner, C. M., \& Ritchie, J. R. B. (2003). The meaning and measurement of destination image. Journal of Tourism Studies, 14(1), 37-48.

Fauri, F.A. (2012). La metamorfosi dell'economia forlivese nel secondo dopoguerra, in G. Gambetta (Eds), Un riformista lungimirante. Angelo Satanassi (1925-2011), Bologna.

Fornell, C., \& Larcker, D. F. (1981). Evaluating structural equation models with unobservable variables and measurement error. Journal of Marketing Research,18(1), 39-50.

Gallarza, M.G., Saura, L.G., \& García, H.C. (2002). Destination image: towards a conceptual framework. Annals of Tourism Research, 29(1), 56-78.

Giovannetti, E. (2010). Il caso di Predappio. IBC, Rivista dell'Istituto per i Beni Artistici e Culturali della Regione Emilia-Romagna, 27(2), 1-3.

Ghirardo, D.Y. (1980). Italian Architects and Fascist Politics: An Evaluation of the Rationslist's Role in Regime Building. Journal of the Society of ARchitectural Historians, 39(2), 109127.

Goulding, C., \& Domic, D. (2009). Heritage, identity and ideological manipulation: The case of Croatia. Annals of Tourism Research, 36(1), 85-102.

Graham, B., \& Howard, P. (2008). Heritage and Identity. In Graham and Howard (eds). The Ashgate Research Companion to Heritage and Identity. Ashgate.

Gursoy, D., Chi, C.G., \& Dyer, P. (2010). Local's attitudes toward mass and alternative tourism: the case of Sunshine Coast, Australia. Journal of Travel Research, 49(3), 381394. 
Gursoy, D., \& Rutherford, D.G. (2004). Host Attitudes toward Tourism: An Improved Structural Model. Annals of Tourism Research, 31, 495-516.

Hall, C. M. (2008). Tourism planning: policies, processes and relationships. Pearson Education.

Hair, J. F., Black,W. C., Babin, B. J., \& Anderson, R. E. (2010). Multivariate data analysis (7th ed.). New Jersey: Pearson Education.

Harvey, D. (2008). The History of Heritage. In Graham and Howard (eds). The Ashgate Research Companion to Heritage and Identity. Ashgate.

Hawke, S. K. (2010). Belonging: the contribution of heritage to sense of place. International Centre for Cultural and Heritage Studies, Newcastle upon Tyne UK: University of Newcastle upon Tyne.

Hollinshead, K. (1992). White gaze, red people- shadow visions: The disindentification of Indians in cultural tourism. Leisure Studies, 11(1), 43-64.

Iorio, M., \& Corsale, A. (2014). Community-based tourism and networking: Viscri, Romania. Journal of Sustainable Tourism, 22(2), 234-255.

Kontogeorgopoulos, N., Churyen, A., \& Duangsaeng, V. (2014). Success factors in community-based tourism in Thailand: The role of luck, external support, and local leadership. Tourism Planning \& Development, 11(1), 106-124.

Ko, D. W., \& Stewart, W. P. (2002). A structural equation model of residents' attitudes for tourism development. Tourism Management, 23(5), 521-530.

Lee, C.K., Kang, S.K., Long, P., \& Reisinger, Y. (2010). Residents' perceptions of casino impacts: A comparative study. Tourism Management, 31(2), 189-201.

Lynch, K. (1960). The Image of the City. The technology press \& Harvard university press. Cambridge.

Lowenthal, D. (1996). Possessed by the past. The heritage crusade and the spoils of history. New York, 1-338.

McCabe, S., \& Stokoe, E.H. (2004). Place and identity in tourist accounts. Annals of Tourism Research, 31(3), 601-622.

McKercher, B., Wang, D., \& Park, E. (2015). Social impact as a function of place change. Annals of tourist research, 50, 52-66.

McGehee, N. G., \& Andereck, K. L. (2004). Factors predicting rural residents' support of tourism. Journal of Travel Research, 43(2), 131-140. 
Oldendick, R.W. (2012). Survey Research Ethics. In: Gideon L. (eds) Handbook of Survey Methodology for the Social Sciences. Springer, New York.

Petzet M. (2004) Principles of preservation. An Introduction to the International Charters for Conservation and Restoration 40 Years after the Venice Charte, ICOMOS open archives. Raffaello Sanzio (1515), Lettera di Raffaello a Papa Leone X, Letter to Pope Leone X, in Baldassarre Castiglione, Le Lettere, Ed: Guido La Rocca, Mondadaori, Milano 1978, 531-542.

Ramkissoon, H., \& Nunkoo, R. (2011). City image and perceived tourism impact: evidence from Port Louis, Mauritius. International Journal of Hospitality and Tourism Administration, 12(2), 123-143.

Ratz, T. (2006). Interpretation in the house of terror, Budapest. In M. K. Smith \& M. Robinson (Eds.), Cultural tourism in a changing world: Politics, participation and (re)presentation, Clevedon: Channel View Publications.

Roushanzamir; E. L, \& Kreshel, P.J. (2001). Gloria and Anthony visit a plantation: History into heritage at 'Laura: A Creole Plantation'. In G. M. S. Dann \& A. V. Seaton (Eds.), Slavery, contested heritage and thanatourism (177-200). New York, NY: The Haworth Press.

Scheyvens, R. (1999). Ecotourism and the empowerment of local communities. Tourism Management, 20, 245-249.

Schroeder, T. (1996). The relationship of residents' image of their state as a tourist destination and their support for tourism. Journal of Travel Research, 34(4), 71-73.

Šešić Dragićević M., \& Mijatović Rogač L. (2014). Balkan Dissonant Heritage Narratives (and Their Attractiveness) for Tourism, American Journal of Tourism Management, 3(1B), 10-19.

Smith, L. (2006). Heritage as a Cultural Process. The Uses of Heritage, London and New York: Routledge.

Stylidis, D., Biran, A., Sit, J., \& Szivas, M. (2014). Residents' support for tourism development: The role of residents' place image and perceived tourism impacts. Tourism Management, $45,260-274$.

Timothy, D. J. (2011). Cultural heritage and tourism: An introduction, Channel View Publications, Bristol. 
Tunbridge, J. E., \& Ashworth, G. J. (1996). Dissonant heritage: the Management of the Past as a Resource in Conflict, Chichester.

Twigger-Ross, C.L., \& Uzzel, D.L. (1996). Place and identity process. Journal of Environmental Psychology, 16, 205-220.

UNESCO (2002). Universal declaration of cultural diversity, Unesco, Paris.

UNESCO (2003). Convention for the Safeguarding of the Intangible Cultural Heritage, Paris.

Wight, A. C. (2016). Lithuanian genocide heritage as discursive formation. Annals of Tourism Research, 59(4), 60-78.

Primary Historical Sources - 1920th and 1930th Newspapers

La Stampa (13 October 1926). L'onorevole Mussolini a Forlì.

La Stampa (11 April 1928). 11 ritorno di Mussolini a Roma: l'omaggio di 500 maestri alla Tomba della Madre del duce.

La Stampa (17 May 1928). La tappa più breve.

La Stampa (14 September 1930). Mentre si Corre la Predappio-Roma.

La Stampa (30 July 1931). Il Duce in Romagna.

La Stampa (28 August 1931). Bimbi delle colonie fasciste alla tomba di Rosa Mussolini

La Stampa (21 August 1932). Vibranti manifestazioni di Popolo accolgono Mussolini a Forlì

La Stampa (1 August 1935). Una lapide nella casa delle generazioni contadine dei Mussolini.

La Stampa (19 September 1936). Il duce inaugura il grande aeroporto di Forlì.

La Stampa (29 December 1938). Il duce inaugurerà a Forlì il villaggio Alessandro Mussolini.

La Stampa (7 October 1941). La giornata del duce a Forlì: L'inaugurazione del collegio Bruno Mussolini e la visita all'Istituto Alessandro Mussolini.

La Stampa (31 August 1957). Incidenti presso la bara di Mussolini.

La Stampa (3-4 October 1957). Predappio un mese dopo.

La Stampa (10 August 1972). Predappio in cerca di turisti, restaura la tomba di Mussolini.

La Stampa (30 July 1983). Tensioni, saluti romani e molti nostalgici a Predappio per il centenario di Mussolini. 


\begin{tabular}{|c|c|c|c|c|c|}
\hline & & \multicolumn{2}{|c|}{ Forlì } & \multicolumn{2}{|c|}{ Predappio } \\
\hline & & $\mathrm{Nr}$. & $\%$ & $\mathrm{Nr}$. & $\%$ \\
\hline \multirow[t]{7}{*}{ Age } & $<25$ & 45 & 20.93 & 35 & 10.64 \\
\hline & $25-34$ & 59 & 27.44 & 44 & 13.37 \\
\hline & $35-44$ & 36 & 16.74 & 91 & 27.66 \\
\hline & $45-54$ & 34 & 15.81 & 59 & 17.93 \\
\hline & $55-64$ & 24 & 11.16 & 47 & 14.29 \\
\hline & $65-74$ & 11 & 5.12 & 33 & 10.03 \\
\hline & $>75$ & 7 & 3.26 & 20 & 6.08 \\
\hline \multirow[t]{2}{*}{ Gender } & M & 115 & 53.49 & 175 & 53.19 \\
\hline & $\mathrm{F}$ & 100 & 46.51 & 154 & 46.81 \\
\hline \multirow[t]{7}{*}{$\begin{array}{l}\text { Number of } \\
\text { years lived in } \\
\text { the city }\end{array}$} & $<25$ & 80 & 37.21 & 95 & 28.88 \\
\hline & $25-34$ & 56 & 26.05 & 58 & 17.63 \\
\hline & $35-44$ & 28 & 13.02 & 59 & 17.93 \\
\hline & $45-54$ & 26 & 12.09 & 39 & 11.85 \\
\hline & $55-64$ & 15 & 6.98 & 37 & 11.25 \\
\hline & $65-74$ & 7 & 3.26 & 28 & 8.51 \\
\hline & $>75$ & 4 & 1.86 & 13 & 3.95 \\
\hline \multirow[t]{4}{*}{$\begin{array}{l}\text { Level of } \\
\text { education }\end{array}$} & Elementary & 10 & 4.65 & 38 & 11.55 \\
\hline & Intermediate school & 46 & 21.40 & 68 & 20.67 \\
\hline & Secondary School & 98 & 45.58 & 174 & 52.89 \\
\hline & degree & 61 & 28.37 & 48 & 14.59 \\
\hline \multirow[t]{10}{*}{ Employment } & Manager/ Practictioner & 10 & 4.65 & 14 & 4.26 \\
\hline & Self-employed & 42 & 19.53 & 70 & 21.28 \\
\hline & White collar & 38 & 17.68 & 84 & 25.53 \\
\hline & Teacher & 10 & 4.65 & 3 & 0.91 \\
\hline & Blue collar & 13 & 6.05 & 33 & 10.03 \\
\hline & Housewife & 12 & 5.58 & 10 & 3.04 \\
\hline & Student & 42 & 19.53 & 18 & 5.47 \\
\hline & Retired & 28 & 13.02 & 65 & 19.76 \\
\hline & Looking for job & 16 & 7.44 & 21 & 6.38 \\
\hline & Other & 3 & 1.40 & 11 & 3.34 \\
\hline
\end{tabular}


Table 2. The measurement of the latent factors

\begin{tabular}{|c|c|c|}
\hline Constructs & Question & Label \\
\hline SUPPORT & $\begin{array}{l}\text { Would you be interested in knowing } \\
\text { more about the Rationalist } \\
\text { architecture (1920s-1930s) in your } \\
\text { town? } \\
\text { Would you like your town be } \\
\text { included in a tourist itinerary of } \\
\text { rationalist buildings? } \\
\text { Would you be in favour of } \\
\text { increasing tourism flows to your } \\
\text { city? }\end{array}$ & $\begin{array}{l}\text { Know } \\
\text { Route } \\
\text { Flow }\end{array}$ \\
\hline $\begin{array}{l}\text { PLACE IMAGE } \\
\text { ENVIRONMENT }\end{array}$ & $\begin{array}{l}\text { Standard of living } \\
\text { Green area and cleanliness } \\
\text { Safety }\end{array}$ & $\begin{array}{l}\text { Tenure } \\
\text { Green } \\
\text { Safety }\end{array}$ \\
\hline $\begin{array}{l}\text { PLACE IMAGE 2- SOCIAL AND } \\
\text { CULTURA ACTIVITIES }\end{array}$ & $\begin{array}{l}\text { Places for leisure and socialization } \\
\text { Cultural and recreational activities }\end{array}$ & $\begin{array}{l}\text { Leisure } \\
\text { Cultural }\end{array}$ \\
\hline $\begin{array}{l}\text { PLACE IMAGE } 3 \text { - CULTURAL } \\
\text { HERITAGE }\end{array}$ & Cultural heritage & Heritage \\
\hline RATIONALISM & $\begin{array}{l}\text { Do you know that many buildings in } \\
\text { your town are important in the } \\
\text { history of architecture? } \\
\text { Do you know that there are many } \\
\text { rationalist buildings in your town? } \\
\text { FORLI': } \\
\text { Do you know that many buildings in } \\
\text { your town were built during the } \\
\text { Fascist period?* }\end{array}$ & $\begin{array}{l}\text { Build } \\
\text { Rational } \\
\text { Fascist }\end{array}$ \\
\hline $\begin{array}{llll}\text { IDENTITY } & 1- & - & \text { ANCIENT } \\
\text { HERITAGE } & & & \\
\end{array}$ & San Domenico Museum & MSD \\
\hline $\begin{array}{llll}\text { IDENTITY } & 2- & - & \text { DISSONANT } \\
\text { HERITAGE } & & & \end{array}$ & $\begin{array}{l}\text { FORLI': } \\
\text { Modern Architecture } \\
\text { PREDAPPIO: } \\
\text { Downtown } \\
\text { Food Market }\end{array}$ & $\begin{array}{l}\text { DT } \\
\text { FM }\end{array}$ \\
\hline $\begin{array}{l}\text { IDENTITY } 3-\text { NOSTALGIC } \\
\text { DISSONANT HERITAGE }\end{array}$ & $\begin{array}{l}\text { PREDAPPIO: } \\
\text { Cemetery of San Cassiano } \\
\text { Tomb of Mussolini }\end{array}$ & $\begin{array}{l}\mathrm{CC} \\
\mathrm{TM} \\
\end{array}$ \\
\hline
\end{tabular}

*This items was excluded in the analysis on Predappio because all interviewed residents responded yes 


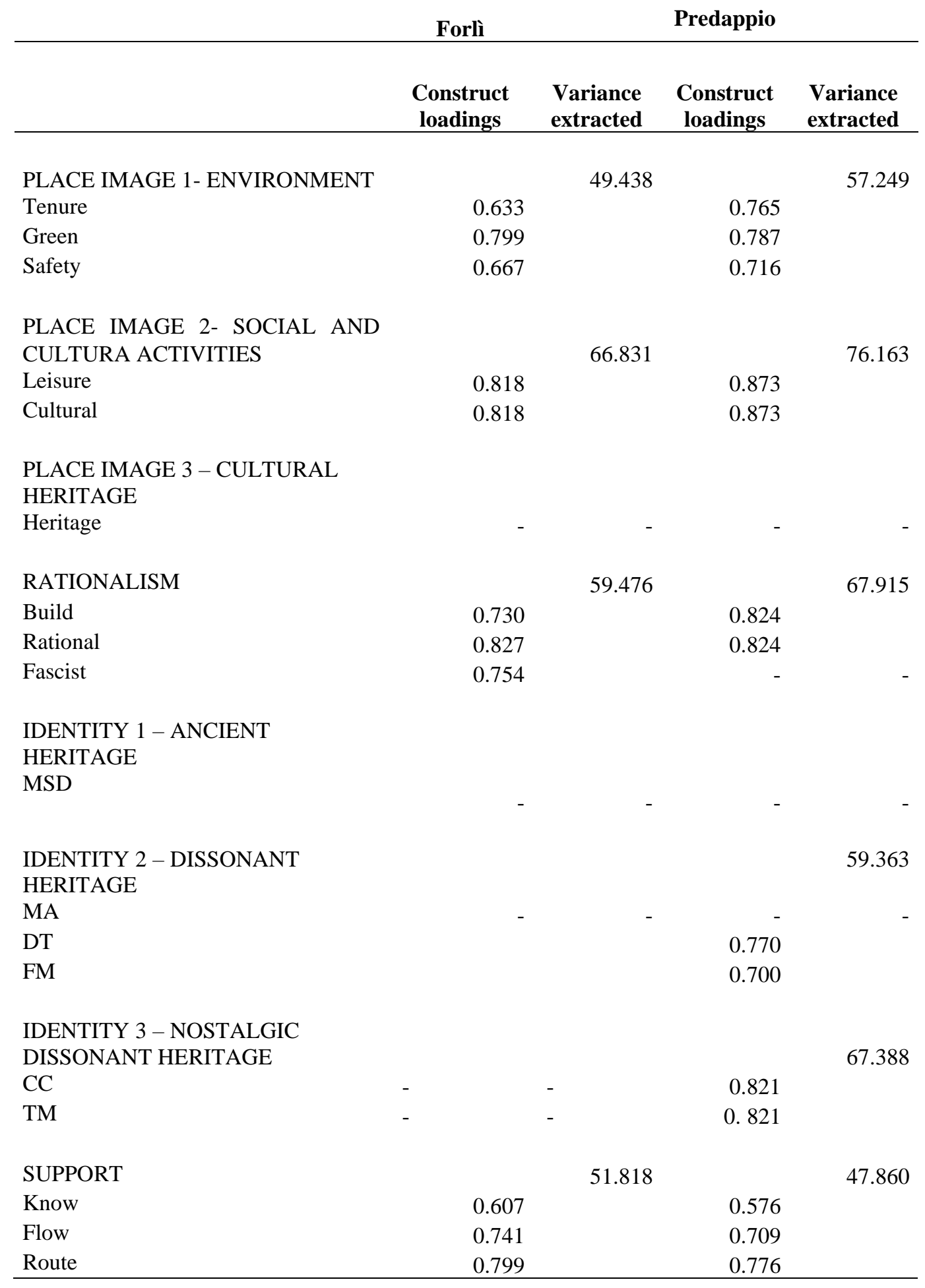




\begin{tabular}{lcc}
\hline & Forlì & Predappio \\
\hline PLACE IMAGE 1- ENVIRONMENT --> SUPPORT & 0.00 & $-0.43^{* * *}$ \\
PLACE IMAGE 2- SOCIAL AND CULTURA ACTIVITIES --> & & -0.19 \\
SUPPORT & $0.23^{* *}$ & -0.34 \\
PLACE IMAGE 3-CULTURAL HERITAGE --> SUPPORT & $-0.20^{*}$ & $1.20^{* * *}$ \\
RATIONALISM --> SUPPORT & $0.32^{* * *}$ & - \\
IDENTITY 1 - ANCIENT HERITAGE --> SUPPORT & $0.39 * * *$ & $0.94^{* * *}$ \\
IDENTITY 2 - DISSONANT HERITAGE --> SUPPORT & - & $-1.82^{* * *}$ \\
IDENTITY 3 - NOSTALGIC DISSONANT HERITAGE - -> SUPPORT & & \\
& 58.37 & $575.60^{* * *}$ \\
Chi-Square & 0.02 & 0.14 \\
RMSEA & 0.99 & 0.92 \\
GFI
\end{tabular}

$*$ p-value $10 \%, * * p$-value $5 \%$, *** p-value $1 \%$ 
Figure 1. Theoretical model

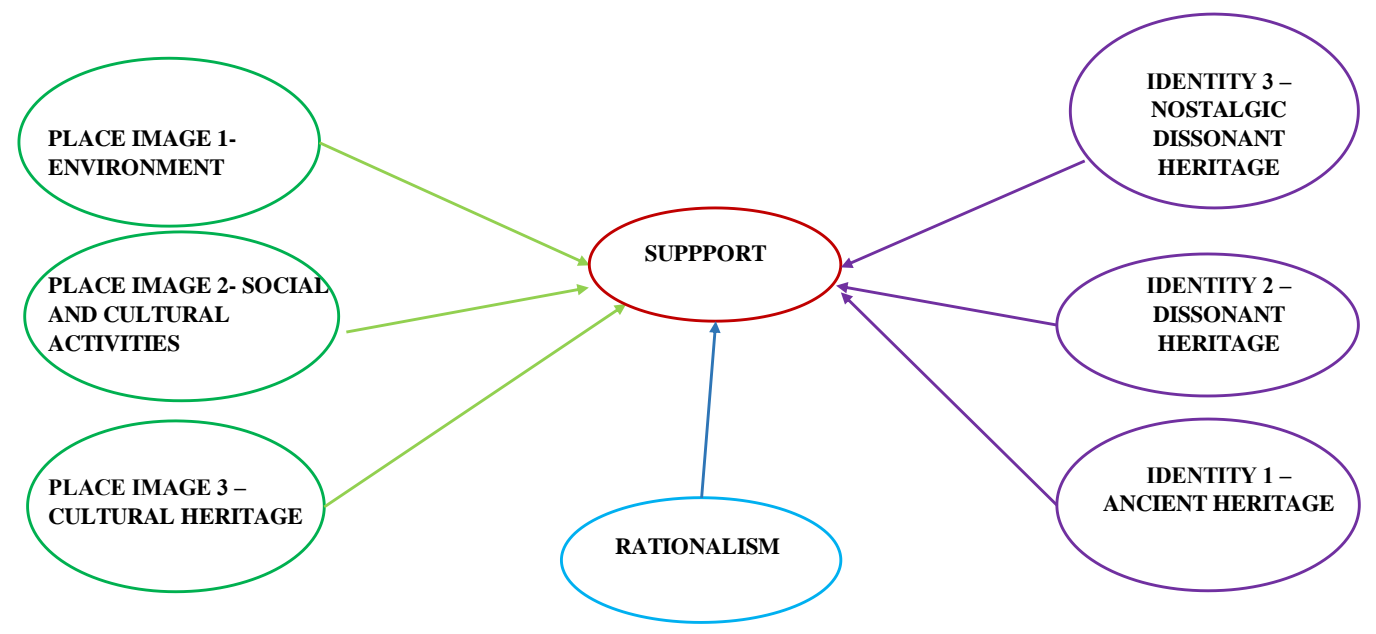


Figure 2. Atrium network

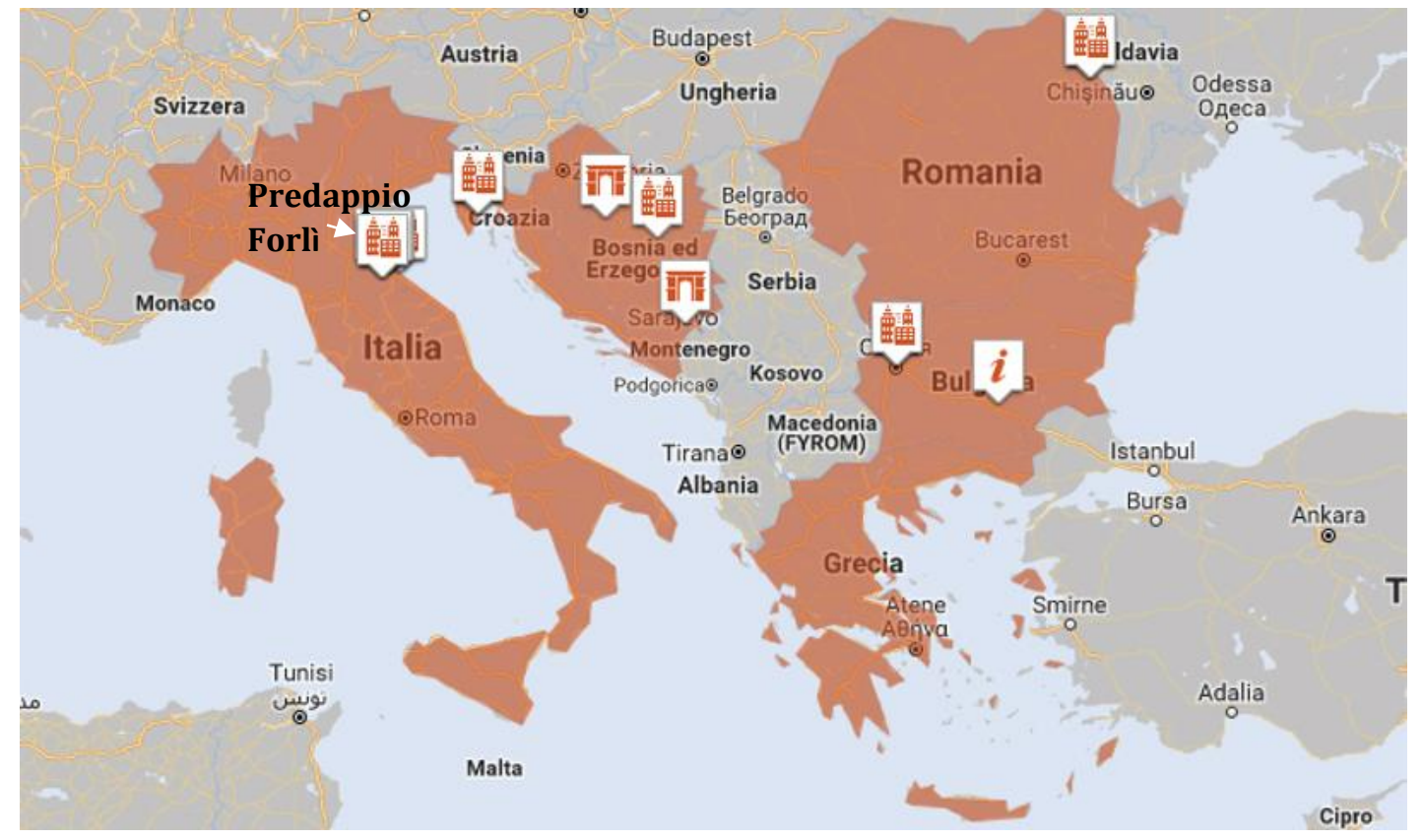


Figure 3. Residents' perceptions of their town (mean values)

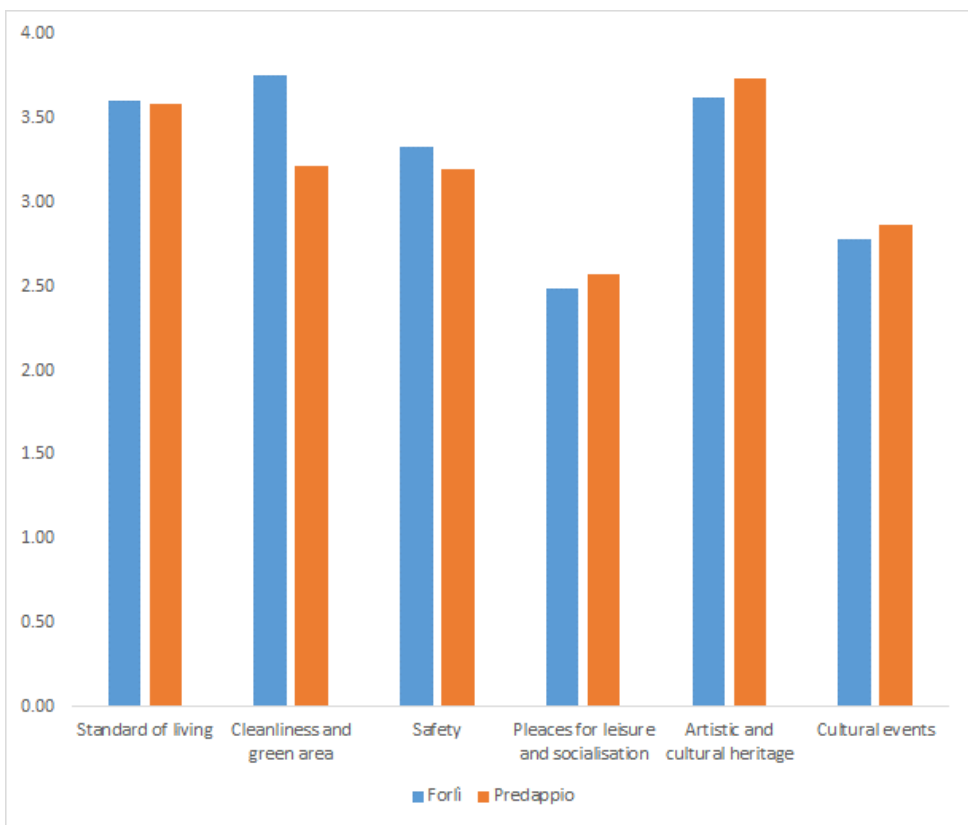


Figure 4. Residents' knowledge of interwar architecture

Do you know that many build ings in your town were built during the Fascist period?

Do you know that there are many rationalist buildings in your town?

Do you know that many build ings in your town are important in the history of architecture?
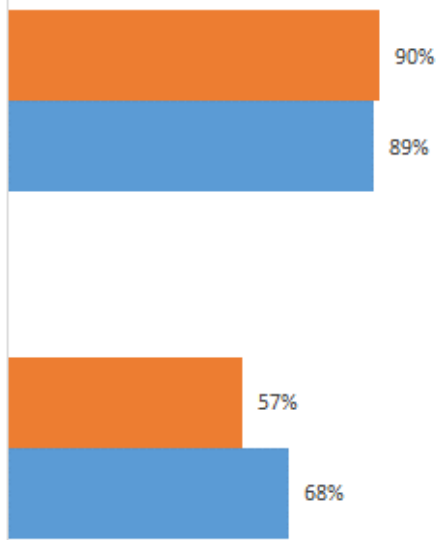

$\begin{array}{lllllll}0 \% & 20 \% & 40 \% & 60 \% & 80 \% & 100 \% & 120 \%\end{array}$

- Predappio a Forli 
Figure 5. Residents' perceptions of their identity

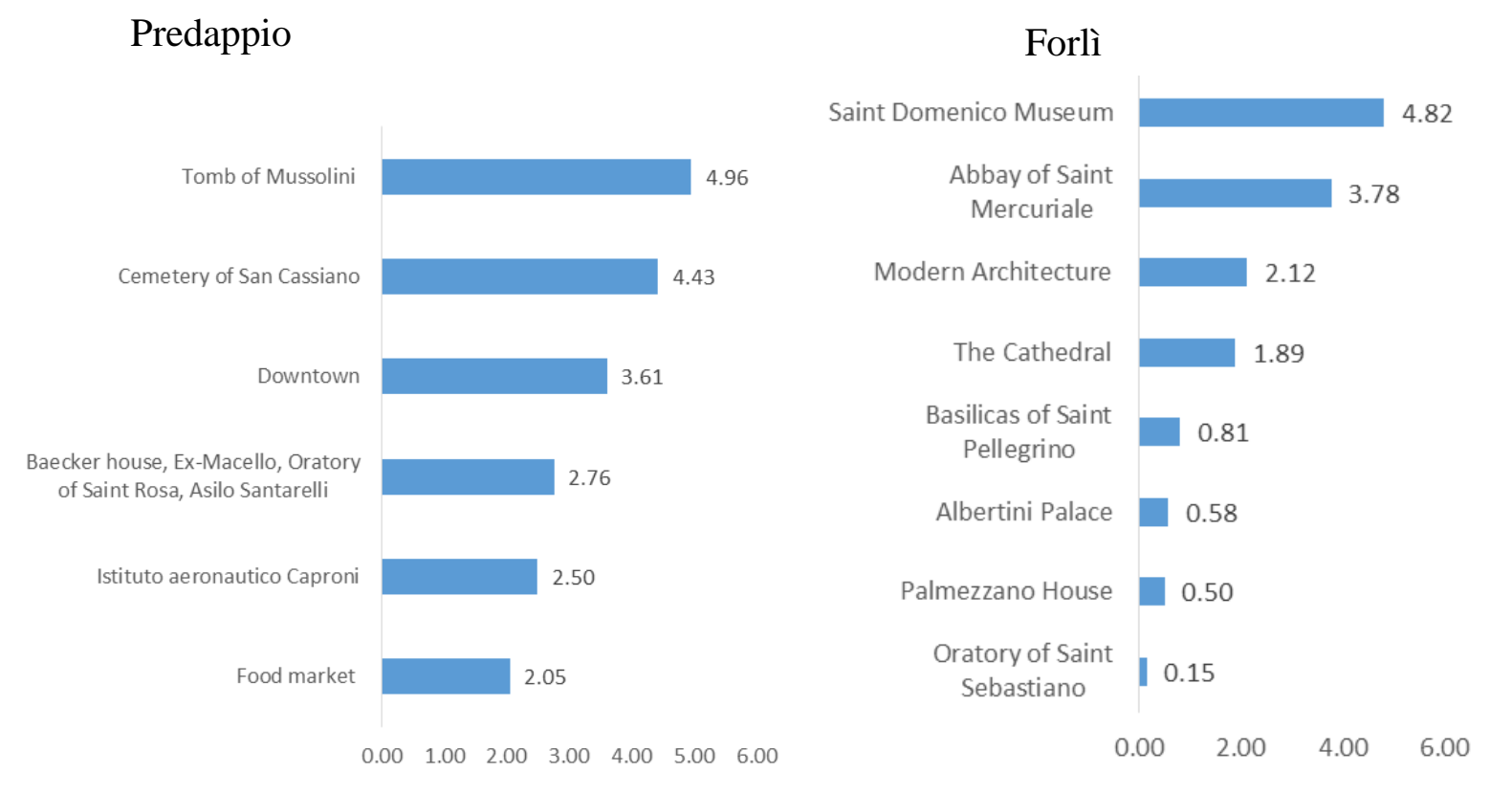


Figure 6. Residents' support for tourism

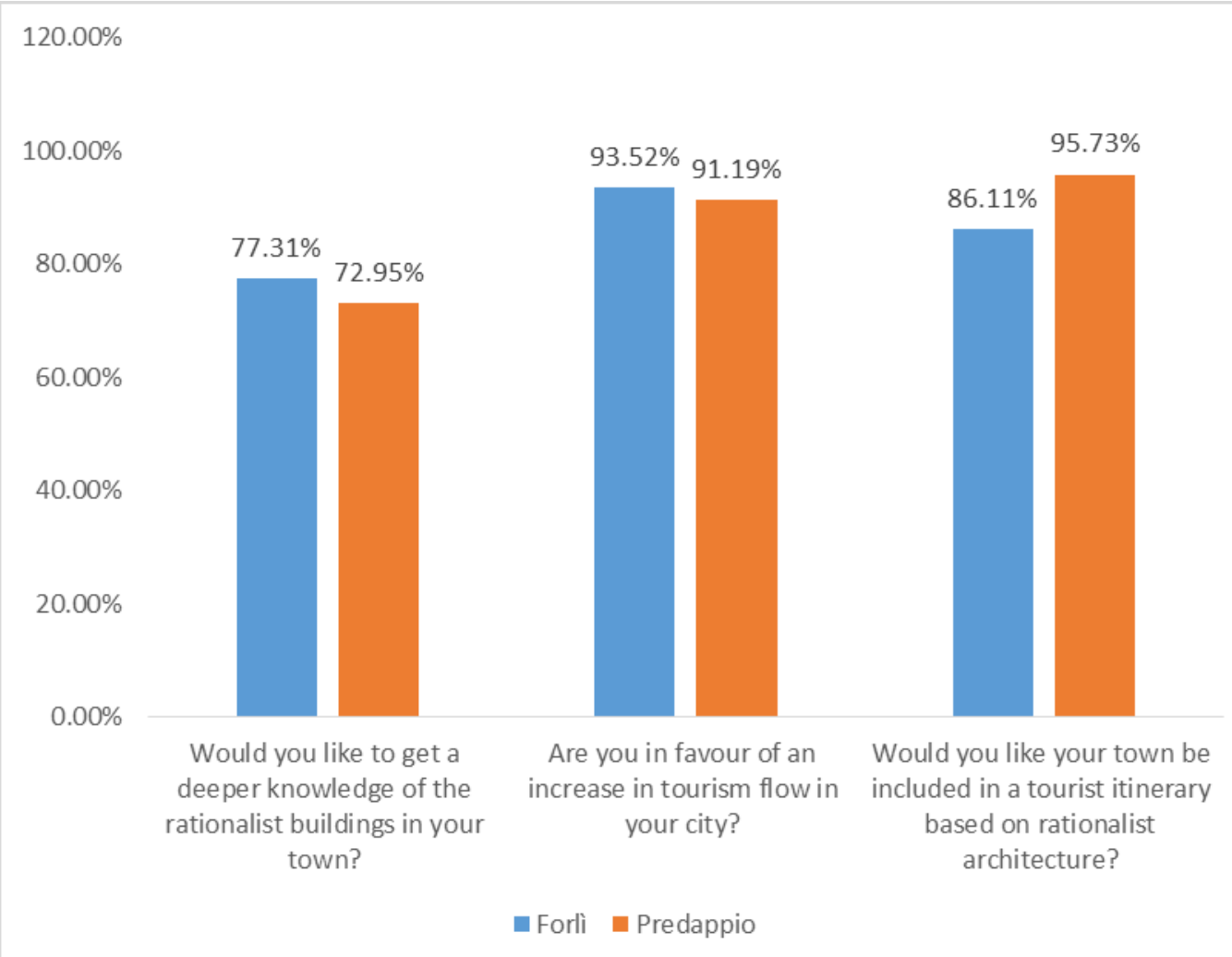


Table 1. Sample description

\begin{tabular}{|c|c|c|c|c|c|}
\hline & & \multicolumn{2}{|c|}{ Forlì } & \multicolumn{2}{|c|}{ Predappio } \\
\hline & & Nr. & $\%$ & Nr. & $\underline{\%}$ \\
\hline \multirow[t]{7}{*}{ Age } & $\leq 25$ & $\underline{45}$ & $\underline{20.93}$ & $\underline{35}$ & $\underline{10.64}$ \\
\hline & $\underline{25-34}$ & $\underline{59}$ & 27.44 & $\underline{44}$ & $\underline{13.37}$ \\
\hline & $\underline{35-44}$ & $\underline{36}$ & $\underline{16.74}$ & $\underline{91}$ & $\underline{27.66}$ \\
\hline & $\underline{45-54}$ & $\underline{34}$ & $\underline{15.81}$ & $\underline{59}$ & $\underline{17.93}$ \\
\hline & $\underline{55-64}$ & $\underline{24}$ & $\underline{11.16}$ & $\underline{47}$ & $\underline{14.29}$ \\
\hline & $65-74$ & $\underline{11}$ & $\overline{5.12}$ & $\underline{33}$ & 10.03 \\
\hline & $>75$ & $\underline{7}$ & $\overline{3.26}$ & $\underline{20}$ & $\underline{6.08}$ \\
\hline \multirow[t]{2}{*}{ Gender } & $\underline{\mathrm{M}}$ & $\underline{115}$ & $\underline{53.49}$ & $\underline{175}$ & $\underline{53.19}$ \\
\hline & $\underline{F}$ & $\underline{100}$ & $\underline{46.51}$ & $\underline{154}$ & $\underline{46.81}$ \\
\hline \multicolumn{6}{|l|}{$\frac{\text { Number of }}{\text { years lived in }}$} \\
\hline \multirow[t]{7}{*}{ the city } & $\leq 25$ & $\underline{80}$ & $\underline{37.21}$ & $\underline{95}$ & $\underline{28.88}$ \\
\hline & $\overline{25-34}$ & $\overline{56}$ & $\overline{26.05}$ & $\overline{58}$ & $\overline{17.63}$ \\
\hline & $35-44$ & $\underline{28}$ & $\underline{13.02}$ & $\underline{59}$ & 17.93 \\
\hline & $\underline{45-54}$ & $\underline{26}$ & $\underline{12.09}$ & $\underline{39}$ & $\underline{11.85}$ \\
\hline & $55-64$ & $\underline{15}$ & $\underline{6.98}$ & $\underline{37}$ & $\underline{11.25}$ \\
\hline & $65-74$ & $\underline{7}$ & $\underline{3.26}$ & $\underline{28}$ & $\underline{8.51}$ \\
\hline & $\geq$ & $\underline{4}$ & $\underline{1.86}$ & $\underline{13}$ & $\underline{3.95}$ \\
\hline \multirow{4}{*}{$\frac{\text { Highest level }}{\underline{\text { of education }}}$} & Elementary & $\underline{10}$ & $\underline{4.65}$ & $\underline{38}$ & $\underline{11.55}$ \\
\hline & Intermediate school & $\underline{46}$ & $\underline{21.40}$ & $\underline{68}$ & $\underline{20.67}$ \\
\hline & $\frac{\text { Secondary School }}{\text { Bachelor/master }}$ & $\underline{98}$ & $\underline{45.58}$ & $\underline{174}$ & $\underline{52.89}$ \\
\hline & degree & $\underline{61}$ & $\underline{28.37}$ & $\underline{48}$ & $\underline{14.59}$ \\
\hline \multirow[t]{10}{*}{ Employment } & $\begin{array}{l}\text { Manager/ } \\
\text { Practictioner }\end{array}$ & $\underline{10}$ & $\underline{4.65}$ & $\underline{14}$ & $\underline{4.26}$ \\
\hline & Self-employed & $\underline{42}$ & $\underline{19.53}$ & $\underline{70}$ & $\underline{21.28}$ \\
\hline & White collar & $\underline{38}$ & 17.68 & $\underline{84}$ & 25.53 \\
\hline & Teacher & $\underline{10}$ & $\underline{4.65}$ & $\underline{3}$ & $\underline{0.91}$ \\
\hline & Blue collar & $\underline{13}$ & $\underline{6.05}$ & $\underline{33}$ & $\underline{10.03}$ \\
\hline & $\underline{\text { Housewife }}$ & $\underline{12}$ & $\underline{5.58}$ & $\underline{10}$ & $\underline{3.04}$ \\
\hline & Student & $\underline{42}$ & $\underline{19.53}$ & $\underline{18}$ & $\overline{5.47}$ \\
\hline & Retired & $\underline{28}$ & $\underline{13.02}$ & $\underline{65}$ & $\underline{19.76}$ \\
\hline & Looking for job & $\underline{16}$ & 7.44 & $\underline{21}$ & $\underline{6.38}$ \\
\hline & Other & $\underline{3}$ & 1.40 & $\underline{11}$ & $\underline{3.34}$ \\
\hline
\end{tabular}


Table 2. The measurement of the latent factors

\begin{tabular}{|c|c|c|}
\hline$\underline{\text { Constructs }}$ & Question & Label \\
\hline SUPPORT & $\begin{array}{l}\text { Would you be interested in knowing more about } \\
\text { the Rationalist architecture (1920s-1930s) in your } \\
\text { town? } \\
\text { Would you like your town be included in a } \\
\text { tourist itinerary of rationalist buildings? } \\
\text { Would you be in favour of increasing tourism } \\
\text { flows to your city? }\end{array}$ & $\begin{array}{l}\underline{\text { Know }} \\
\underline{\text { Route }} \\
\underline{\text { Flow }}\end{array}$ \\
\hline PLACE IMAGE 1- ENVIRONMENT & $\begin{array}{l}\text { Standard of living } \\
\text { Green area and cleanliness } \\
\text { Safety }\end{array}$ & $\begin{array}{l}\underline{\text { Tenure }} \\
\underline{\text { Green }} \\
\underline{\text { Safety }}\end{array}$ \\
\hline $\begin{array}{l}\text { PLACE IMAGE 2- SOCIAL AND } \\
\underline{\text { CULTURA ACTIVITIES }}\end{array}$ & $\begin{array}{l}\text { Places for leisure and socialization } \\
\text { Cultural and recreational activities }\end{array}$ & $\begin{array}{l}\underline{\text { Leisure }} \\
\text { Cultural }\end{array}$ \\
\hline $\begin{array}{l}\text { PLACE IMAGE } 3 \text { - CULTURAL } \\
\underline{\text { HERITAGE }}\end{array}$ & Cultural heritage & $\underline{\text { Heritage }}$ \\
\hline$\underline{\text { RATIONALISM }}$ & $\begin{array}{l}\text { Do you know that many buildings in your town } \\
\text { are important in the history of architecture? } \\
\text { Do you know that there are many rationalist } \\
\text { buildings in your town? } \\
\text { FORLI': } \\
\text { Do you know that many buildings in your town } \\
\text { were built during the Fascist period?* }\end{array}$ & $\begin{array}{l}\underline{\text { Build }} \\
\text { Rational } \\
\underline{\text { Fascist }}\end{array}$ \\
\hline $\begin{array}{llll}\text { IDENTITY } & 1- & \text { ANCIENT } \\
\text { HERITAGE } & & & \end{array}$ & $\underline{\text { San Domenico Museum }}$ & $\underline{\mathrm{MSD}}$ \\
\hline $\begin{array}{llll}\text { IDENTITY } & 2-\text { DISSONANT } \\
\underline{\text { HERITAGE }} & & \\
\end{array}$ & $\begin{array}{l}\text { FORLI': } \\
\text { Modern Architecture } \\
\text { PREDAPPIO: } \\
\text { Downtown } \\
\text { Food Market }\end{array}$ & $\begin{array}{l}\underline{\mathrm{MA}} \\
\frac{\mathrm{DT}}{\mathrm{FM}}\end{array}$ \\
\hline $\begin{array}{l}\text { IDENTITY } 3-\text { NOSTALGIC } \\
\text { DISSONANT HERITAGE }\end{array}$ & $\begin{array}{l}\frac{\text { PREDAPPIO: }}{\text { Cemetery of San Cassiano }} \\
\text { Tomb of Mussolini }\end{array}$ & $\frac{\mathrm{CC}}{\underline{\mathrm{TM}}}$ \\
\hline
\end{tabular}

*This items was excluded in the analysis on Predappio because all interviewed residents responded yes 


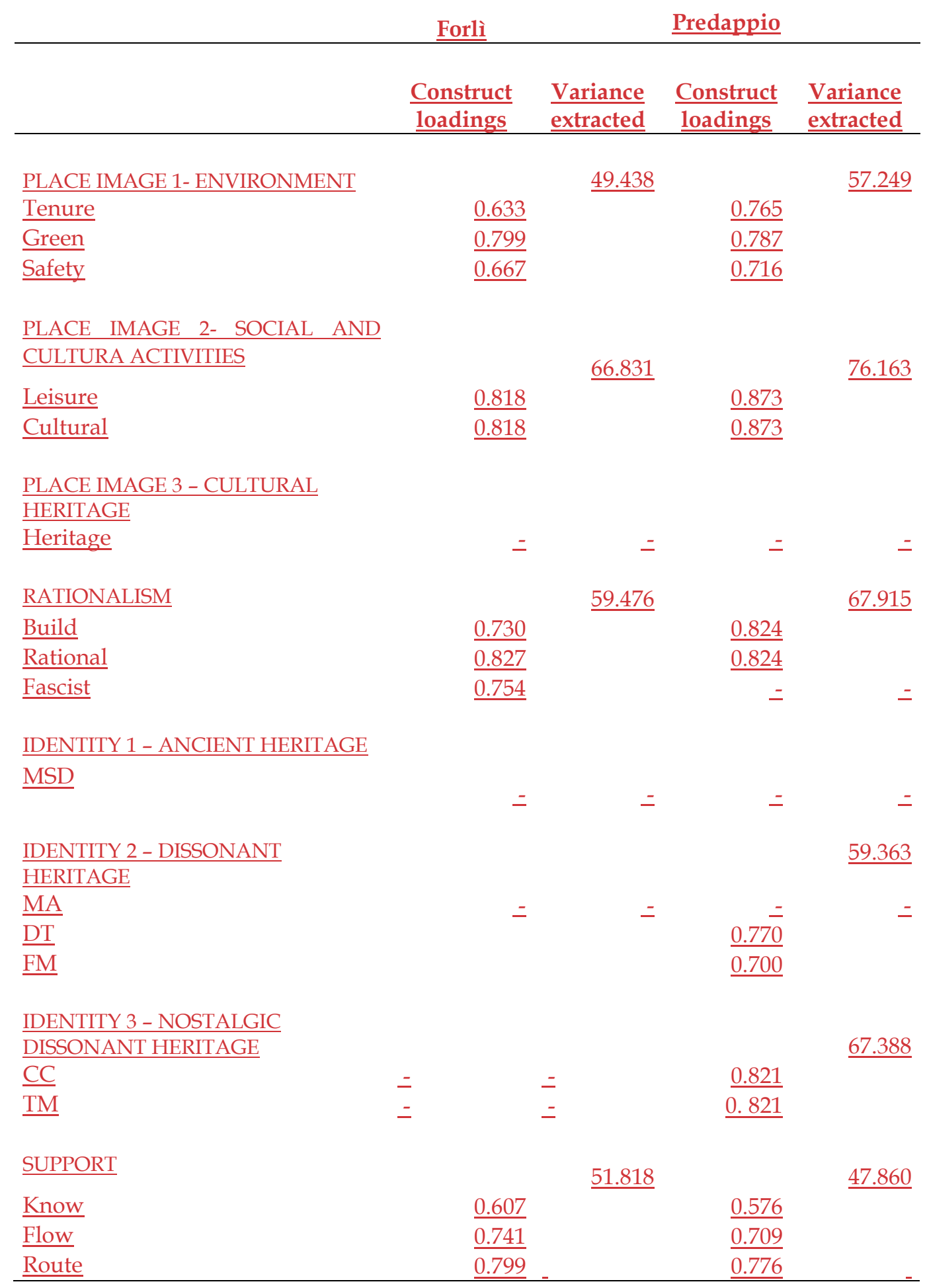


$\underline{\text { Table 4. Parameter estimates }}$

\begin{tabular}{|c|c|c|}
\hline & Forlì & Predappio \\
\hline PLACE IMAGE 1- ENVIRONMENT --> SUPPORT & $\underline{0.00}$ & $\underline{-0.43^{* * *}}$ \\
\hline PLACE IMAGE 2- SOCIAL AND CULTURA ACTIVITIES --> SUPPORT & $\underline{-0.19}$ & $\underline{-0.34}$ \\
\hline PLACE IMAGE 3 - CULTURAL HERITAGE --> SUPPORT & $\underline{0.23^{* *}}$ & $\overline{-0.10}$ \\
\hline$\underline{\text { RATIONALISM --> SUPPORT }}$ & $\underline{-0.20^{*}}$ & $\underline{1.20 * * *}$ \\
\hline IDENTITY 1 - ANCIENT HERITAGE --> SUPPORT & $\underline{0.32^{* * * *}}$ & $=$ \\
\hline IDENTITY 2 - DISSONANT HERITAGE --> SUPPORT & $\underline{0.39 * * *}$ & $\underline{0.94^{* * *}}$ \\
\hline IDENTITY 3 - NOSTALGIC DISSONANT HERITAGE - -> SUPPORT & $=$ & $\underline{-1.82^{* * *}}$ \\
\hline Chi-Square & $\underline{58.37}$ & $\underline{575.60 * * *}$ \\
\hline RMSEA & $\underline{0.02}$ & $\underline{0.14}$ \\
\hline GFI & $\underline{0.99}$ & $\underline{0.92}$ \\
\hline
\end{tabular}

${ }^{*}$ p-value $10 \%,{ }^{* *}$-value $5 \%,{ }^{* * *}$ p-value $1 \%$ 